\title{
Virgin Coconut Oil and Its Antimicrobial Properties against Pathogenic Microorganisms: A Review
}

\author{
Nur Ainatul Mardia Mohamad Nasir \\ Student \\ Department of Biotechnology \\ Kulliyyah of Science \\ International Islamic University Malaysia \\ Pahang, Malaysia
}

Anil Azura Jalaludin

Department of Biotechnology

Kulliyyah of Science

International Islamic University Malaysia

Pahang, Malaysia

\author{
Zurainie Abllah \\ Department of Pediatrics \\ Orthodontic \& Dental Public Health \\ Kulliyyah of Dentistry \\ International Islamic University Malaysia \\ Pahang, Malaysia \\ drzura@iium.edu.my \\ Intan Azura Shahdan \\ Department of Biomedical Science \\ Kulliyyah of Allied Health Sciences \\ International Islamic University Malaysia \\ Pahang, Malaysia
}

\author{
Wan Nor Hayati Wan Abd Manan \\ Department of Restorative \\ Kulliyyah of Dentistry, International Islamic University Malaysia \\ Pahang, Malaysia
}

\begin{abstract}
Virgin coconut oil (VCO) is the purest form of coconut oil, essentially water-clear or colourless that consists mainly of medium chain saturated fatty acids. For over many decades, the biological properties of VCO have been widely explored and investigated due to their antimicrobial potentials. The large concentration of medium chain fatty acids (MCFAs) including lauric acid (LA) and its monoglyceride form, monolaurin makes VCO effective in their mode of actions against pathogenic microorganisms. Thus, VCO could be used as a daily supplement or an alternative remedy against microbial infections. We review and discuss the current state of knowledge of VCO studies and focus on its antibacterial, antifungal, and antiviral activities aiming to unravel the underlying mechanisms of VCO inhibition of these pathogenic microorganisms.
\end{abstract}

Keywords-virgin coconut oil, medium chain fatty acids, antimicrobial, antibacterial, antifungal, antiviral

\section{INTRODUCTION}

Cocos nucifera, a vital member of the family Arecaceae (palm family) popularly known as coconut, coco, coco-da-bahia, or coconut-of-the-beach [1], is being produced and exported by India, Sri Lanka, Malaysia, and Indonesia [2]. Often referred to as the "tree of life", every part of the coconut tree can be either consumed by humans or animals or converted into other products such as brushes from the coir, spoon and ladle from the shell, food wrapper from the weaved leaves, and house furniture from the trunk. Not only known for providing meat alternative, juice, and milk, coconut is also a good source of oil [3].

Derived from copra, coconut oil is colourless to the pale brownish yellow dried kernel or 'meat' of coconut. The Malays in the Peninsular Malaysia refer to coconut oil as true oil and in India, it has been recognised as the healthiest oil in Ayurvedic medicine, a teaching based on the Veda (circa 1,500 BC) [4]. Also, coconut was valued as a medicinal plant for centuries in the Thai traditional medicine [5]. Records also show that in the United States, coconut oil has been one of the major sources of dietary fats, prior to the introduction of American edible oil (soybean and corn) in the mid1940s [6].

Unlike palm oil, coconut oil can be routinely homemade, easily available oil that is natural and free from chemical treatment. Coconut oil has a low oxidation point where oxidation process only takes place after two years of storage, making it very stable due to high presence of saturated fat [7]. Usage of coconut oil as frying and cooking oil has been well known, but its uses as a cheaper alternative to relatively expensive butterfat in filled milk, filled cheese, and ice cream makings may need more public awareness and promotion. The non-food application of coconut oil is acknowledged in the production of soaps, rubbers, elastomers, and also derivatives such as alkanolamides [8]. Generally, coconut oil is available in three major forms, which are refined coconut oil (RCO), copra oil (CO), and virgin coconut oil (VCO) $[9,10]$. 


\section{LITERATURE REVIEW}

\section{A. Virgin coconut oil}

The Asian Pacific Coconut Community in 2003 defines $\mathrm{VCO}$ as the oil resulting from the fresh and mature kernel (or solid endosperm or meat) of the coconut through mechanical and natural means, either with the presence of heat or not, without any alteration or transformation of the oil [11]. In essence, VCO is produced by wet extraction process of the fresh endosperm of the coconut [12] while $\mathrm{CO}$ is obtained by dry extraction process of the dried endosperm of the coconut fruit [13]. The extraction process of VCO does not involve the use of thermal or chemical and also exposure to very high temperatures or UV treatments, making it more beneficial with all of the natural active components such as antioxidants, vitamins, and polyphenols are being retained $[14,15]$. On the other hand, RCO is produced by the extraction of the oil from dried coconut flesh, followed by chemical refinement, bleaching, and deodorization processes [16]. Due to the refining process, the RCO lacks the taste and fragrance of coconut while VCO, which never undergo any refining process, has a distinct coconut flavour and aroma compared to $\mathrm{CO}$ and [10].

VCO has been acknowledged as the healthiest crop oil and can be extensively used in various fields such as food, beverage, medicinal, pharmaceutical, nutraceutical, and cosmetics [17]. The incredible health benefit of VCO is due to the unique type of saturated fats presents in the oil. Therefore it is considered the healthiest of all dietary oils [18]. Since its first commercial introduction by the Western establishments, VCO has caught the interest of vast majority of public and researchers alike. The beneficial medicinal properties of the oil are fast spreading although testimonials may outnumber real laboratory data.

\section{B. Fatty acids composition of vco}

While the other common plant edible oils usually consist of long chain fatty acids (LCFAs), VCO is an exception to this rule by containing both short chain fatty acids (SCFAs) and MCFAs, the latter thus classified as medium chain triglycerides (MCTs). MCTs are MCFAs esters of glycerol, and edible MCTs oils are normally gained through lipid fractionation from edible fats such as coconut oil and milk [19]. MCTs were originally produced in the late 1940s by $\mathrm{Dr}$ Vigen Babayan of the Drew Chemical Company in an effort to find uses for the top fractions of coconut oil fatty acids, thus became commercially available in 1955 [20]. Although they are categorised as saturated fats, MCTs outshine the other saturated fats and oils due to their distinctive properties of having shorter chain length and smaller molecules making them more quickly absorbed and metabolised by the body [20,21]. Due to these distinctive properties, MCTs have been used in the treatment of various malabsorption ailments.

Being a type of saturated fat, MCTs are readily digestible, while LCTs, although it is saturated, are difficult to digest [22].The term MCFAs refers to a mixture of saturated fatty acids which commonly consists of 6-12 carbons chain [19,23]. The MCFAs of VCO consists of caproic acid (C6), caprylic acid (C8), capric acid (C10), and lauric acid (C12). The LCFAs of VCO consist of myristic acid (C14), palmitic acid (C16), palmitoleic acid (C16:1), stearic acid (C18), oleic acid (C18:1), linoleic acid (C18:2), and linolenic acid (C18:3) [24].

In 2007, Department of Standards Malaysia has affirmed that the composition of VCO's fatty acids falls within the range as specified in Table I. VCO naturally contains a 3:1 ratio mixture of MCFAs and LCFAs [25] where the saturated MCFAs comprises two-thirds of coconut oil's fatty acids, the saturated LCFAs are less than one-third, and the unsaturated fatty acids are less than a tenth of its fatty acids [26]. Coconut oil is about $90 \%$ saturated fatty acids and is highly saturated oil [27]. Remarkably, coconut oil has the major amount of caprylic acid, capric acid and LA among the palm oils and can be considered as the most saturated oil compared to palm, soybean, and corn oils and animal fats [8]. Coconut oil is hence a unique vegetable oil because it is the only oil where approximately $50 \%$ of the fatty acid composition is LA $[22,28]$.

TABLE I. FATTY ACIDS COMPOSITION OF VCO
\begin{tabular}{|c|c|c|}
\hline Common name & Carbon number & Composition (\%) \\
\hline Caproic acid & C $6: 0$ & $0.80-0.95$ \\
\hline Caprylic acid & C $8: 0$ & $8.00-9.00$ \\
\hline Capric acid & C $10: 0$ & $5.00-7.00$ \\
\hline Lauric acid & C $12: 0$ & $47.00-50.00$ \\
\hline Myristic acid & C $14: 0$ & $17.00-18.50$ \\
\hline Palmitic acid & C $16: 0$ & $7.50-9.50$ \\
\hline Palmitoleic acid & C $16: 1$ & ND \\
\hline Stearic acid & C $18: 0$ & 2.503 .50 \\
\hline Oleic acid & C $18: 1$ & $4.50-6.00$ \\
\hline Linoleic acid & C $18: 2$ & $0.70-1.50$ \\
\hline Linolenic acid & C $18: 3$ & ND \\
\hline
\end{tabular}

Dayrit [22] attributed many of the advantages of coconut oil to the existence of LA. Similarly, DebMandal \& Mandal [29] and Marina et al. [30] declared that the most abundant and powerful MCFAs in VCO is LA which comprises nearly 50\% of coconut's fat content. Previously, Santoso et al. [31] also reported that the fatty acid composition of lipid from kopyor (mature coconut) meat was dominated by LA. Interestingly, studies had shown that human breast milk and VCO share similar fat content. Kabara [4] and Hayatullina et al. [32] highlighted that $60 \%$ of VCO MCFAs is similar in composition to human breast milk. LA and linoleic acids amount to 5\% and 15\%, respectively, of total fatty acids in human milk that function as determinants of anti-infective activity [33]. Also, Koletzko et al. [34] reported that major part of the lipids of the mother's milk is composed of the saturated fatty acids $(\mathrm{C} 12-\mathrm{C} 18)$.

Our body converts LA into monolaurin, a monoglyceride composed of a glycerol unit and it is present in many animals and plants [35]. Monolaurin has been identified by many researchers to be the protective substance that keeps infants against viral and 
bacterial infections [36]. Even though there is no patent data pertaining to how much monolaurin is actually formed from LA in the human body, nevertheless, there is evidence that some are formed. MCFAs have a number of unique properties which give them advantages over the most common LCFAs. At the level of the mitochondrion, MCFAs can increase oxidative metabolism in muscle.

While most LCFAs are stored in the adipocytes [37], MCFAs are far less likely to be stored in adipocytes and because of this; MCFAs have been reported to suppress fat deposition [27] through improved thermogenesis and fat oxidation in animal and human subject [19]. The fact that MCFAs are less efficiently stored than other fatty acids and are highly prone to oxidative metabolism once ingested, implies that they have a short half-life and are unlikely to promote obesity via direct storage in adipocytes [38]. Moreover, in contrast to LCFAs, MCFAs can prevent the induction of oxidative stress that usually arises due to excess lipid intake [39].

It was not a very long time ago that many epidemiological and nutritional studies suggested that the consumption of high amounts of saturated fat and cholesterol [40] led to high blood cholesterol which ultimately left $\mathrm{VCO}$ at a disadvantage and received a bad reputation. However, the tides have turned for VCO where recent clinical studies have shown multiple positive outcomes offering counter arguments recognising them as highly valuable and healthy oils [30]. Studies have shown that the use of VCO in diet can regulate blood fats and increase the HDL cholesterol level while decreasing the LDL significantly [15] thus disproving the myth that coconut oil increases cholesterol in the body.

\section{Antimicrobial activities of virgin coconut oil}

The high potentials of coconut oil as medicine were ascertained by Kabara in the 1970s, who found coconut oil's antibacterial, antiviral, and antifungal activities were exerted by its MCFAs [41]. The recognition of coconut oil antimicrobial activities was also reported by Hierholzer and Kabara [42] which focused on virucidal effects of monolaurin RNA and DNA viruses. Recently, experimental outcomes from many studies discovered that monolaurin had not only antimicrobial activity against various gram-positive and gram-negative bacterial cells $[1,3,43]$ but also antifungal and antiviral properties $[44,45,46,47,48]$. Manohar et al. [49] showed that coconut oils, when used as food flavouring agents, exhibited a wide range of antimicrobial activities. Among MCFAs, LA and its derivatives were found to be the most effective antimicrobial agents for foods and cosmetics [46,50]. The antimicrobial effects of fatty acids are additive and their total concentration is vital for bacterial growth inhibition [35].

\section{Antibacterial action of coconut oil}

MCFAs with 6 to 12 carbons, possessed significant yet skewed activity against gram-positive bacteria, but not against gram-negative bacteria. McKellar et al. [51] reported that MCFAs and LCFAs could not actually inhibit the growth of gram-negative bacteria. However, in a current study, ample inhibition was observed for the gram-negative bacteria, Escherichia coli and Salmonella enteritidis [7]. Via diffusion agar method, Sihombing et al. [52] found that VCO was more effective against Bacillus cereus, a gram-positive bacterium compared to $\mathrm{E}$. coli due to the presence of MCFAs and its monoglyceride form especially monolaurin. Widiyarti et al. [53] showed that the antibacterial activity of LA was very potent and was effective against Staphylococcus aureus.

Similarly, the effect of LA on the growth of bacteria was investigated and it was evident from the study that LA was the most effective inhibitor against S. aureus [54] and Pseudomonas aeruginosa, a common opportunistic bacterium that causes infection in immunocompromised individuals [55]. Further, Verallo-Rowell et al. [56] found that VCO was useful in the treatment of atopic dermatitis caused by S. aureus. Wang and Johnson [57] examine the effectiveness of monolaurin on the growth of Listeria monocytogenes, a human foodborne pathogen. A transmission electron scanning (TEM) analysis was done to observe the morphological changes in the bacteria cells. Results of their study showed that cytoplasmic content of treated bacteria cell appeared to separate from cell envelope. Breakage of the cell envelope also was observed.

Moreover, studies on medium-chain saturated and long-chain unsaturated monoglycerides added to supplement infant formula established that both can effectively inactivate a gram-negative bacterium, Haemophilus influenzae [58] while Thaweboon et al. [43] reported that coconut oil exhibited antimicrobial activity against Streptococcus mutans by evaluating its effect on biofilm models formed on salivary-coated microtitre plates. It has been also reported that fatty acids extracts obtained after the hydrolysis of coconut fat showed high antimicrobial potential against grampositive bacteria, B. cereus and L. monocytogenes and gram-negative bacteria, E. coli and S. enteritidis [7]. Only recently, Odel et al. [59] further proved that LA could hinder the maturity of S. aureus, B. cereus, E. coli, and Salmonella thypimurium, but the inhibition was still lower than the Ciprofloxacin, an antibiotic used to treat a number of bacterial infections. Khor et al. [25] concluded that the acidic $\mathrm{pH}$ nature of $\mathrm{VCO}$ between 2.52 and 4.38 may be an important attribute to its microbial inhibitory action. The antibacterial activity of MCFAs has been summarized in Table II.

\section{E. Antifungal action of coconut oil}

Presently, VCO and its MCFAs have been used broadly against fungi and most of the researches were focusing on Candida albicans, the most common and frequently isolated fungus from the human body. An in vitro study by Arnfinnsson et al. [60] showed that capric acid and LA had the strong ability to inhibit the growth of $\mathrm{C}$. albicans. The result reported that even at 
low concentration, LA was able to inhibit the yeast cell but still, it required a longer than usual incubation time. The reduction in infectivity titers suggested some fungicidal activity by capric acid and LA. Huang et al. [61] stated that different kinds of fatty acids displayed different patterns of inhibition against oral bacteria. Their study demonstrated that MCFAs had a significant anti-Candida activity while SCFAs and LCFAs showed limited bioactivity against oral fungal species.

According to the report of Ogbolu et al. [62], C. albicans, C. glabrata, C. tropicalis, C. parapsilosis, C. stellatoidea, and C. krusei that had been isolated from the surrounding environment of Ibadan, Nigeria were sensitive to coconut oil. An agar well diffusion technique was used to test the susceptibilities of Candida species to coconut oil and the results revealed that at $100 \%$ concentration of coconut oil, all the Candida species were sensitive to coconut oil while at the lowest concentration $(0.79 \%)$, only $35 \%$ of Candida species were affected by coconut oil. Among all the species tested, C. albicans showed the highest susceptibility to coconut oil while C. krusei demonstrated the utmost resistance to coconut oil.

Antifungal activity of coconut oil also has been studied by Winarsi and Purwanto [63] where a vaginal candidiasis patient was successfully treated with zincenriched VCO that might have acted as an immunostimulants. Haematological test by Micros-OT was done on a part of the blood and using ELISA, the level of Interleukin-2 (IL-2) and immunoglobuline-G (IgG) were tested with the use of plasma. Results showed that enriched VCO retained neutrophil and natural killer cells numbers in the body, but improved number of T-cytotoxic and T-helper cells. The enriched VCO also increased the level of IL-2 while the level of IgG changed from equivocal to negative. Latest, in comparison with ketoconazole, antifungal activity of $\mathrm{C}$. albicans isolated from children with early childhood caries was tested using coconut oil [64] and it was validated that coconut oil had comparable antifungal activity with ketoconazole. The antifungal activity of coconut oil against $\mathrm{C}$. albicans was also found to be higher than probiotic, a live microorganism that grants a health benefit on the host when administered in adequate amounts. Fungal activity of coconut oil and its MCFAs have been summarized in Table II.

\section{F. Antiviral action of coconut oil}

The antiviral activity of monolaurin was tested against many enveloped human RNA and DNA viruses and the results concluded that all viruses were reduced in infectivity at $1 \%$ concentration of the monolaurin additive [42]. In the presence of LA, Hornung et al. [45] indicated that the replication of vesicular stomatitis virus (VSV) was inhibited by several orders of magnitude where the inhibitory effect was reversible. They reported that the quantity of matrix protein, one of the five functional proteins encoded by the virus placed in the plasma membrane, was found to be noticeably decreasing after the treatment with LA. Similarly, in the same year, a study on inactivation of visna virus (VV), VSV, and herpes simplex virus (HSV) by free fatty acids and monoglycerides was done. With the uses of a series of antiviral activity assays and electron microscopy, Thormar et al. [65] reported that MCFAs could inactivate $\mathrm{VV}$ and other enveloped viruses causing more than a 3,000- to 10,000 -fold reduction in virus titer.

Correspondingly, by having coconut oil in the daily diet, Dayrit [66] stated that the viral load of HIV patients could be reduced, showing that it has an antiviral effect. According to Enig [67], the AIDS organisation, Keep Hope Alive, has documented several HIV/AIDS patients whose viral load reduced to undetectable levels when they added coconut oil to their daily diet or their anti-HIV medication. The positive antiviral action was seen not only with the monoglyceride of LA but with coconut oil itself indicating that coconut oil was metabolised to monoglyceride forms of caprylic acid, capric acid, and LA to which it must owe its antipathogenic activity. A year later, Enig [68] claimed that monolaurin could inactivate viruses including HIV, measles virus, HSV, $\mathrm{VSV}, \mathrm{VV}$, and cytomegalovirus (CV) to some extent.

In addition, Arora et al. [69] stated that coconut oil was very effective against various viruses with lipid capsules, such as VV, CV, and also Epstein-Barr virus. Yuniwarti et al. [70] investigated the effect of VCO on lymphocyte and CD4 (cluster of differentiating), a surface protein on $\mathrm{T}$ lymphocyte, in chicken which had been vaccinated against the avian influenza virus. The study which applied the completely randomised factorial design method concluded that fatty acids of VCO were able to boost the amount of lymphocyte and CD4 on vaccinated or unvaccinated broiler chicken showing that VCO was potentially acting as an immunomodulator which therefore could increase chicken immunity and in combating a viral infection. The antiviral activity of VCO and its MCFAs has been summarised in Table II.

\section{G. Action mechanism of coconut oil against pathogenic microorganisms}

The exact mechanism by which VCO exerts its antimicrobial effects is still largely unknown. Of the coconut derived metabolites, LA may have the most antimicrobial activity [71]. According to DebMandal and Mandal [29], LA and its monoglyceride found in coconut oil are effective in obliterating a wide variety of lipid-coated bacteria by disintegrating their lipid membranes. The MCFAs in coconut oil principally destroy microbial organisms by disturbing their membranes, thus interfering with virus assembly and maturation [69]. Besides, monolaurin is known to produce highly ordered membranes, which is thought to disrupt membrane function by affecting signal transduction due to blockage of promoters, uncoupling of energy systems, altered respiration state, and altered amino acid uptake [72]. 
TABLE II. EFFECT OF VCO ON THE PATHOGENIC MICROORGANISMS

\begin{tabular}{|c|c|c|c|}
\hline $\begin{array}{c}\text { Antimicrobial } \\
\text { properties }\end{array}$ & Compound & $\begin{array}{c}\text { Inhibited } \\
\text { Microorganisms }\end{array}$ & References \\
\hline \multirow[t]{5}{*}{ Antibacterial } & $\begin{array}{l}\text { Monolaurin, } \\
\text { Lauric acid } \\
\text { and linoleic } \\
\text { acid }\end{array}$ & $\begin{array}{c}\text { Listeria } \\
\text { monocytogenes }\end{array}$ & $\begin{array}{c}\text { Wang \& } \\
\text { Johnson, } \\
1992\end{array}$ \\
\hline & $\begin{array}{l}\text { Monolaurin } \\
\text { and } \\
\text { monocaprin }\end{array}$ & $\begin{array}{c}\text { Helicobacter } \\
\text { pylori }\end{array}$ & $\begin{array}{c}\text { Bergsson et } \\
\text { al., } 2002\end{array}$ \\
\hline & Coconut oil & $\begin{array}{l}\text { Streptococcus } \\
\text { mutans }\end{array}$ & $\begin{array}{l}\text { Thaweboon } \\
\text { et al., } 2011\end{array}$ \\
\hline & $\begin{array}{l}\text { Lauric acid } \\
\text { and } \\
\text { monolaurin }\end{array}$ & Bacillus cereus & $\begin{array}{l}\text { Sihombing } \\
\text { et al., } 2014\end{array}$ \\
\hline & Monolaurin & $\begin{array}{c}\text { Staphylococcus } \\
\text { aureus }\end{array}$ & $\begin{array}{c}\text { Widiyarti et } \\
\text { al., } 2009\end{array}$ \\
\hline \multirow[t]{9}{*}{ Antifungal } & Lauric acid & $\begin{array}{c}\text { Staphylococcus } \\
\text { aureus }\end{array}$ & $\begin{array}{c}\text { Kitahara et } \\
\text { al., } 2004\end{array}$ \\
\hline & $\begin{array}{c}\text { Virgin } \\
\text { coconut oil }\end{array}$ & $\begin{array}{c}\text { Pseudomonas } \\
\text { aeruginosa }\end{array}$ & $\begin{array}{l}\text { Silalahi et } \\
\text { al., } 2014\end{array}$ \\
\hline & MCFAs & $\begin{array}{l}\text { Staphylococcus } \\
\text { aureus }\end{array}$ & $\begin{array}{l}\text { Verallo- } \\
\text { Rowell et } \\
\text { al., } 2008 \\
\end{array}$ \\
\hline & MCFAs & $\begin{array}{c}\text { Escherichia coli } \\
\text { and Salmonella } \\
\text { enteritidis }\end{array}$ & $\begin{array}{l}\text { Parfene et } \\
\text { al., } 2013\end{array}$ \\
\hline & $\begin{array}{c}\text { Lauric acid } \\
\text { and capric } \\
\text { acid }\end{array}$ & $\begin{array}{l}\text { Candida } \\
\text { albicans }\end{array}$ & $\begin{array}{c}\text { Amfinnsson } \\
\text { et al., } 2001\end{array}$ \\
\hline & Coconut oil & $\begin{array}{l}\text { Candida sp.; } C \text {. } \\
\text { albicans, } \\
\text { C.tropicalis, C. } \\
\text { parapsilosis, } C \text {. } \\
\text { stellatoidea, and } \\
\text { C. krusei, }\end{array}$ & $\begin{array}{l}\text { Ogbolu, } \\
2007\end{array}$ \\
\hline & $\begin{array}{c}\text { Virgin } \\
\text { coconut oil }\end{array}$ & Candida $\mathrm{sp}$. & $\begin{array}{l}\text { Winarsi \& } \\
\text { Purwanto, } \\
2008\end{array}$ \\
\hline & Coconut oil & $\begin{array}{l}\text { Candida } \\
\text { albicans }\end{array}$ & $\begin{array}{l}\text { Thaweboon } \\
\text { et al., } 2011\end{array}$ \\
\hline & $\begin{array}{c}\text { Virgin } \\
\text { coconut oil }\end{array}$ & $\begin{array}{l}\text { Candida } \\
\text { albicans }\end{array}$ & $\begin{array}{c}\text { Lima et al., } \\
2015\end{array}$ \\
\hline \multirow[t]{4}{*}{ Antiviral } & Monolaurin & $\begin{array}{c}\text { human RNA and } \\
\text { DNA viruses }\end{array}$ & $\begin{array}{c}\text { Hierholzer } \\
\text { \& Kabara, } \\
1982 \\
\end{array}$ \\
\hline & Lauric acid & $\begin{array}{c}\text { Vesicular } \\
\text { stomatitis virus }\end{array}$ & $\begin{array}{c}\text { Hornung et } \\
\text { al., } 1994\end{array}$ \\
\hline & $\begin{array}{l}\text { Lauric acid } \\
\text { and } \\
\text { monolaurin }\end{array}$ & HIV virus & Enig, 1997 \\
\hline & $\begin{array}{c}\text { Virgin } \\
\text { coconut oil }\end{array}$ & $\begin{array}{c}\text { Avian Influenza } \\
\text { virus }\end{array}$ & $\begin{array}{r}\text { Yuniwarti } \\
\text { et al., } 2012\end{array}$ \\
\hline
\end{tabular}

Monolaurin had been reported to cause a constant increase in leakage of cell membranes of S. aureus [35, 73]. Several researchers suggested that VCO was needed to be metabolised by enzymes prior to releasing its antimicrobial components of MCFAs, caprylic acid, capric acid, and LA. A particularly intriguing and unresolved mystery of the VCO actions concerns the actual mechanism by which fatty acids are bactericidal to pathogens. Although largely unknown, some disruption of the lipid membranes of the susceptible organisms by VCO or its metabolites cannot be entirely overruled [58]. Hierholzer and Kabara [42] suggested that a key factor in the virucidal activity of monolaurin was associated with a generalised disintegration of the cell envelope signifying that solubilisation of the lipids and phospholipids in the cell envelope had occurred. The viral envelope was found to be affected by fatty acids, causing leakage and at even higher concentrations, a complete disintegration of the envelope and the viral particles occurred [65].

Recent electron microscopic evidence of several microbes after being exposed to fatty acids suggested that the cell membranes of Clostridium perfringens, Chlamydia trachomatis, Streptococcus agalactiae, C. albicans, and S. aureus were disrupted with subsequent lysis of the bacteria [71]. Similarly, Warth [74] and Voegas and Correia [75] also supported that micromolar concentrations of fatty acids have a direct effect on the cellular membranes enzymatic activities. Finally, polyunsaturated fatty acids have been documented to inhibit microorganisms through autoxidation and formation of peroxides and radicals [76] and potentially involving bacterial iron [77].

\section{DISCUSSION}

The current findings on the advantageous of VCO especially on its antimicrobial activity have gathered many attentions from researchers around the world to investigate further as control of infections is crucial on the health agenda of many developing countries, and the use of VCO could serve as a cheaper alternative means of controlling infections. Considerably more studies need to be embarked on especially on the action mechanisms of VCO. Molecular studies and tests on VCO's mechanism should be done in order to evaluate its action in detailed particularly on microbe's membrane lipid. It is suggested also that future studies look into the mechanism involving other parts of the microbes that might yield novel knowledge and understanding. New methodologies on how to isolate the single fatty acids and obtaining its bioactive compound also need to be explored as it can be used in the investigation of antimicrobial activity, thus demonstrating the underlying mechanisms.

Despite many research, some limitations of the studies on VCO must be acknowledged. We believe that many researchers are having a great difficulty when dealing with the process to isolate specific compounds from VCO. There is no exact method on how to isolate the compound. Different parameters like temperature, pressure, and time need to be adjusted according to the sample types and target compounds involved. Besides, when running the antimicrobial test, researchers were having a problem in dissolving or diluting the VCO. Methanol, ethanol, and dimethyl sulfoxide (DMSO) are the organic solvents that are being used frequently to dilute VCO. Nevertheless, these solvents have antibacterial property as well, making the test results inaccurate. Until recently, most of the antimicrobial tests were done directly only between the tested microorganisms and the extracts itself. Somehow, in reality, when we are dealing with the microbial infections in the body, there are actually many systems involved, cooperating with each other in combating infections. Hence, a more complex method should be 
considered so that we can create a better environment for testing the antimicrobial activity.

The information discussed in this review explains that VCO possesses various types of fatty acids which have been associated with its biological and medicinal properties. Based on the summary compiled herein on the antimicrobial activities of $\mathrm{VCO}$, it is noted that VCO contains various potent bioactive compounds, most of which might have bactericidal, virucidal, and fungicidal benefits with less or no adverse effects. Above and beyond, the emergence of the microbial resistance, together with the low availability of antimicrobial agents which are often opted as the last resorts have created a threat to the medical community and practitioners alike, demands for a continuous need to explore nature in search of new antimicrobial compounds with novel targets and modes of action. In this regard, researchers are neither wrong nor weak to turn their attention towards antimicrobials of the plant origin. Even though there is much research on coconut oil, extensive research and investigation on the antimicrobial potency of VCO are necessary to validate the use of VCO as a valuable antimicrobial agent and exploit the oil's potential therapeutic benefits to combat various diseases.

\section{ACKNOWLEDGMENT}

Acknowledgments are addressed to the Ministry of Higher Education as the expense of this study was derived from Research Acculturation Grant Scheme (RAGS 15-062-0125) and Fundamental Research Grant Scheme (FRGS 16-020-0519).

\section{REFERENCES}

[1] F.C. Peedikayil, P. Sreenivasan, A. Narayanan, "Effect of coconut oil in plaque related gingivitis-A preliminary report," Nigerian Medical Journal, vol. 56(2), pp. 143-147, 2015.

[2] P. Srivastava, S. Durgaprasad. "Burn wound healing property of Cocos nucifera: An appraisal," Indian J. Pharmacol, vol. 40, pp. 144-146, 2008

[3] J.B. Taheri, F.W. Espineli, H. Lu, M. Asayesh, M. Bakhshi, M.R. Nakhostin, B. Hooshmand, "Antimicrobial effect of coconut flour on oral microflora: An in vitro study," Research Journal of Biological Sciences, vol. 5, pp. 456-459, 2010.

[4] J.J. Kabara, "Health oils from the tree of life (nutritional and health aspects of coconut oil)," Indian Coconut Journal, vol. 31(8), pp. 2-8, 2000.

[5] S. Intahphuak, P. Khonsung, A. Panthong, "Anti-inflammatory, analgesic, and antipyretic activities of virgin coconut oil. Pharmaceutical Biology, vol. 48, pp. 151-157, April 2008

[6] C.S. Dayrit, The truth about coconut oil (the drugstore in a bottle)". Pasig City, Philippines: Anvil Publishing Inc., 2005.

[7] G. Parfene, V. Horincar, A. Kumar, A. Malik, G. Bahrim, "Production of medium chain saturated fatty acids with enhanced antimicrobial activity from crude coconut fat by solid state cultivation of Yarrowia lipolytica," Food Chemistry, vol. 136(3-4), 1345-1349, 2013

[8] L.U.R.L Aureles, F.E.M.R. Odriguez, C.O.E.R. Ean, E.V.M. Ae, T.E.M. Endoza, Variability in fatty acid and triacylglycerol composition of the oil of coconut (Cocos nucifera L.) hybrids and their parentals, 2002.

[9] F.M. Dayrit, O.E.M. Buenafe, E.T. Chainani, I.M.S. De Vera, "Analysis of monoglycerides, diglycerides, sterols, and free fatty acids in coconut (Cocos nucifera L.) oil by 31P NMR spectroscopy," Journal of agricultural and food chemistry, vol. 56(14), pp. 5765-5769, 2008.
[10] K.G. Nevin, TRajamohan, "Food chemistry virgin coconut oil supplemented diet increases the antioxidant status in rats," vol. 99, pp. 260-266, 2006.

[11] V.P. Dia, V.V. Garcia, R.C. Mabesa, E.M. Tecson-Mendoza, E. M. Tecson-Menddonza, "Comparative physicochemical characteristics of virgin coconut oil produced by different methods," Philippine Agricultural Scientist, vol. 88(4), pp. 462 $475,2005$.

[12] B. Iranloye, G. Oludare, M. Olubiyi, "Anti-diabetic and antioxidant effects of virgin coconut oil in alloxan induced diabetic male Sprague Dawley rats," Journal of Diabetes Mellitus, vol. 3(4), pp. 221-226, 2013.

[13] M. Harris, N.A.N Norulaini, W.S.W. Nursyazreen, N. Raihan, A.K.M. Omar, "Solubility of virgin coconut oil in supercritical carbon dioxide," Journal of Food Engineering, vol. 168, pp. 240-244, 2016

[14] A.M. Marina, Y.B. Che Man, S.A.H Nazimah, I. Amin, "Chemical properties of virgin coconut oil," Journal of the American Oil Chemists' Society, vol. 86(4), pp. 301-307, 2009.

[15] K.G. Nevin, T. Rajamohan, "Beneficial effects of virgin coconu oil on lipid parameters and in vitro LDL oxidation," Clinical Biochemistry, vol. 37(9), pp. 830-835, 2004.

[16] F.M. Dayrit, O.E.M. Buenafe, E.T. Chainani, I.M.S. De Vera, "Analysis of monoglycerides, diglycerides, sterols, and free fatty acids in coconut (Cocos nucifera L.) oil by 31P NMR spectroscopy," Journal of agricultural and food chemistry, vol. 56(14), pp. 5765-5769, 2008.

[17] C.Y. Ng, A.W. Mohammad, L.Y. Ng, J.M. Jahim, "Sequentia fractionation of value-added coconut products using membrane processes," Journal of Industrial and Engineering Chemistry, 2014.

[18] A. Vysakh, M. Ratheesh, T.P. Rajmohanan, C. Pramod, S Premlal, B.G. Kumar, P.I. Sibi, "Polyphenolics isolated from virgin coconut oil inhibits adjuvant induced arthritis in rats through antioxidant and anti-inflammatory action," International Immunopharmacology, vol. 20(1), pp. 124-130, 2014.

[19] K. Nagao, T. Yanagita, "Medium-chain fatty acids: Functiona lipids for the prevention and treatment of the metabolic syndrome," Pharmacological Research, vol. 61(3), pp. 208-212, 2010.

[20] J.A. Heydinger, D.K. Nakhasi, "Medium chain triacylglycerols," Journal of Food Lipids, vol. 3(4), pp. 251-257, 1996.

[21] Y.B. Che Man, A.M. Marina, Medium chain triacylglycerol, In F. Shahidi (Ed.), Nutraceutical and specialty lipids and thei coproducts, Boca Raton: Taylor \& Francis Group, 2006, pp. 27 56.

[22] F.M. Dayrit, "Lauric acid is a medium-chain fatty acid, coconu oil is a medium-chain triglyceride," vol. 143, pp. 157-166, December 2014.

[23] B. Marten, M. Pfeuffer, J. Schrezenmeir, "Medium-chain triglycerides," International Dairy Journal, vol. 16(11), pp. 1374-1382, 2006

[24] D.D. Bawalan, K.R. Chapman, Virgin coconut oil:production manual for micro-and village-scale processing. In: FAO (Ed.) Bangkok: Thamada Press, 2006.

[25] Y.P. Khor, S.P Koh, K. Long, S. Long, S.Z.S Ahmad, C.P. Tan, "A comparative study of the physicochemical properties of a virgin coconut oil emulsion and commercial food supplement emulsions," Molecules, vol. 19(7), pp. 9187-9202, 2014

[26] W.G. Padolina, L.Z. Lucas, L.G. Torres, "Chemical and physical properties of coconut oil," Philipp. J. Coconut Stud., vol. 12, pp. 4-17, 1987.

[27] J. Wang, X. Wang, J. Li, Y. Chen, W. Yang, L. Zhang, "Effects of dietary coconut oil as a medium-chain fatty acid source on performance, carcass composition and serum lipids in male broilers," vol. 28(2), pp. 223-230, 2015.

[28] S. Lieberman, M.G. Enig, H.G. Preuss, "A review of monolaurin and lauric acid," Alternative \& Complementary Therapies, vol. 12(6), pp. 310-315, 2006.

[29] M. DebMandal, S. Mandal, "Coconut (Cocos nucifera L. Arecaceae): In health promotion and disease prevention," Asian Pacific Journal of Tropical Medicine, vol. 4(3), pp. 241-247, 2011 
[30] A.M. Marina, Y.B.C. Man, I. Amin, "Virgin coconut oil: emerging functional food oil," Trends in Food Science and Technology, vol. 20(10), pp. 481-487, 2009.

[31] U. Santoso, K. Kazuhiro, T. Ota, T. Tadokorob, A. Maekawab, Nutrient composition of kopyor coconuts (Cocos nucifera L.)," vol. 51(2), pp. 299-304, 1996.

[32] Z. Hayatullina, N. Muhammad, N. Mohamed, I.N. Soelaiman, "Virgin coconut oil supplementation prevents bone loss in osteoporosis rat model," Evidence-Based Complementary and Alternative Medicine, 2012.

[33] M. Hamosh, "BIoactive factors in human milk," vol. 48, February 2001

[34] B. Koletzko, M. Rodriguez-Palmeroa, H. Demmelmaira, N. Fidler, R. Jensen, T. Sauerwalda, "Physiological aspects of human milk lipids," Early Human Development, vol. 65(2), pp. S3-S18, 2001.

[35] P. Tangwatcharin, P. Khopaibool, "Activity of virgin coconut oil, lauric acid or monolaurin in combination with lactic acid against Staphylococcus aureus," Southeast Asian Journal of Tropical Medicine and Public Health, vol. 43(4), pp. 969-985, 2012.

[36] M.G. Enig. (1995) Health and nutritional benefits from coconut oil and its advantages over competing oils. Available: http://coconutboard.gov.in/English-Article-MaryEnig.pdf.

[37] A.C. Rego Costa, E.L. Rosado, M. Soares-Mota, "Influence of the dietary intake of medium chain triglycerides on body composition, energy expenditure and satiety; A systematic review," Nutr. Hosp., vol. 27, pp. 103-108, 2012

[38] M.F. McCarty, J.J. DiNicolantonio, "Lauric acid-rich mediumchain triglycerides can substitute for other oils in cooking applications and may have limited pathogenicity," Open Heart, vol. 3(2), pp. e000467.

[39] M.K. Montgomery, B. Osborne, S.H.J. Brown, L. Small, T.W. Mitchell, G.J. Cooney, N. Turner, "Contrasting metabolic effects of medium- versus long-chain fatty acids in skeletal muscle," Journal of Lipid Research, vol. 54(12), vol. 3322-3333, 2013.

[40] J.B. German, C.J. Dillard, "Commentary saturated fats : what dietary intake?" American Journal of Clinical Nutrition, pp. $550-559,2004$

[41] J.J. Kabara, "Fatty acids and derivatives as antimicrobial agentsA review-Symposium on the pharmacological effects of lipids," AOCS, pp. 1- 13, 1978.

[42] J.C. Hierholzer, J.J. Kabara, "In vitro effects of monolaurin compounds on enveloped RNA and DNA viruses," J. Food Safety, vol. 4, pp. 1-12, 1982

[43] S. Thaweboon, J. Nakaparksin, B. Thaweboon, "Effect of oilpulling on oral microorganisms in biofilm models," Asia J. Public Health, vol. 2(2), pp. 62-66, 2011

[44] D.M. Anang, G. Rusul, J. Bakar, F.H. Ling, "Effects of lactic acid and lauricidin on the survival of Listeria monocytogenes, Salmonella enteritidis and Escherichia coli O157: H7 in chicken breast stored at 4 C," Food Control, vol. 18(8), pp. 961-969, 2007.

[45] B. Hornung, E. Amtmann, G. Sauer, "Lauric acid inhibits the maturation of vesicular stomatitis virus," pp. 353-361, May 1994.

[46] S.K. Yeap, B.K. Beh, N.M. Ali, H.M. Yusof, W.Y. Ho, S.P. Koh, K. Long, "Antistress and antioxidant effects of virgin coconut oil in vivo," Experimental and Therapeutic Medicine, vol. 9(1), pp. 39-42, 2015.

[47] A.M. Akinnuga, S.O. Jeje, O. Bamidele, V.E. Sunday, "Dietary consumption of virgin coconut oil ameliorates lipid profiles in diabetic rats," Physiology Journal, 2014.

[48] M.A. Abujazia, N. Muhammad, A.N. Shuid, I.N Soelaiman, "The effects of virgin coconut oil on bone oxidative status in ovariectomised rat," Evidence-Based Complementary and Alternative Medicine, 2012.

[49] V. Manohar, B. Echard, N. Perricone, C. Ingram, M. Enig, D. Bagchi, H.G. Preuss, "In vitro and in vivo effects of two coconut oils in comparison to monolaurin on Staphylococcus aureus: Rodent studies," Journal of Medicinal Food, vol. 16(6), pp. 499-503, 2013.

[50] A. Khoramnia, A. Ebrahimpour, R. Ghanbari, Z. Ajdari, O.M. Lai, "Improvement of medium chain fatty acid content and antimicrobial activity of coconut oil via solid-state fermentation using a Malaysian Geotrichum candidum," BioMed Research International, 2013

[51] R.C. McKellar, A. Paquet, C.Y. Ma, "Antimicrobial activity of fatty N-acylamino acids against Gram-positive food-borne pathogens," Food Microbiology, vol. 9, pp. 67-76, 1992.

[52] N.T.M. Sihombing, J. Silalahi, D. Suryanto, "Antibacterial activity of aqueous garlic (allium sativum) extracts and virgin coconut oil and their combination against bacillus cereus ATCC 14579 and escherichia coli ATCC 8939," International Journal of ChemTech Research, vol. 6(5), pp. 2774-2782, 2014.

[53] Widiyarti G, Hanafi M, Suwarso WP (2009). Study on The Synthesis of Monolaurin as Antibacterial Agent against Staphylococcus aureus. Indo. J. Chem. 9(1): 99-106.

[54] G. Widiyarti, M. Hanafi, W.P. Suwarso, "Study on the Synthesis of monolaurin as antibacterial agent against Staphylococcus aureus,” Indo. J. Chem., vol. 9(1), pp. 99-106, 2009

[55] J. Silalahi, Yademetripermata, E. de L. Putra, "Antibacterial activity of hydrolyzed virgin coconut oil," Asian Journal of Pharmaceutical and Clinical Research, vol. 7(Suppl. 2), pp. 9094, 2014

[56] Verallo-Rowell, M. Vermén, Dillague, M. Kristine, Syah-Tjundawan, S. Bertha, "Novel antibacterial and emollient effects of coconut and virgin olive oils in adult atopic dermatitis," vol. 19(6), pp. 308-315, 2008.

[57] L. Wang, E. Johnson, "Inhibition of Listeria monocytogenes by fatty acids and monoglycerides," Applied and Environmental Microbiology, vol. 58(2), pp. 624-629, 1992.

[58] C.E. Isaacs, H. Thormar, The role of milk-derived antimicrobial lipids as antiviral and antibacterial agents. In: Immunology of Milk and the Neonate US: Springer US, 1991, pp. 159-165.

[59] F. Odel, D. Siswanta, E. Nurwening, "Isolation and antibacterial activity test of lauric acid from crude coconut oil (Cocos nucifera L.), vol. 18(Mcls 2015), pp. 132-140, 2016.

[60] H. Arnfinnsson, L. Steingri, G. Bergsson, "In vitro killing of Candida albicans by fatty acids and monoglycerides," vol. 45(11), pp. 3209-3212, 2001

[61] C.B. Huang, Y. Alimova, T.M. Myers, J.L. Ebersole, "Shortand medium-chain fatty acids exhibit antimicrobial activity for oral microorganisms," Archives of Oral Biology, vol. 56(7), pp. 650-654, 2011.

[62] D.O. Ogbolu, A.A. Oni, O.A. Daini, A.P. Oloko, "In vitro antimicrobial properties of coconut oil on Candida species in Ibadan, Nigeria," Journal of Medicinal Food, vol. 10(2), pp. 384-387, 2007

[63] H. Winarsi, A. Purwanto, "Virgin coconut oil (VCO) enriched with $\mathrm{Zn}$ as immunostimulator for vaginal candidiasis patient," vol. 15(4), pp. 135-139, 2008

[64] B. Shino, F.C. Peedikayil, S.R. Jaiprakash, G.A. Bijapur, S Kottayi, D. Jose, "Comparison of antimicrobial activity of chlorhexidine , coconut oil, probiotics, and ketoconazole on Candida albicans isolated in children with early childhood caries: An in vitro study, 2016.

[65] H. Thormar, C.E. Isaacs, K. Kim, H.R. Brown, "Inactivation of visna virus and other enveloped viruses by free fatty acids and monoglycerides," Annals of the New York Academy of Sciences, vol. 724(1), pp. 465-471, 1994.

[66] M.G. Enig, "Coconut oil: An anti-bacterial, anti-viral ingredient for food, nutrition and health," AVOC Lauric Symposium, October 1997.

[67] M.G. Enig, "Lauricoils as antimicrobial agents: theory of effect, scientific rationale," Nutrients and Foods in AIDS, vol. 17, pp. $81,1998$.

[68] R. Arora, R. Chawla, R. Marwah, P. Arora, R.K. Sharma, V Kaushik, et al., "Potential of complementary and alternative medicine in preventive management of novel H1N1 flu (Swine flu) pandemic: thwarting potential disasters in the bud," Evid Based Complement Alternat Med, 2011.

[69] E.Y.W. Yuniwarti, W. Asmara, W.T. Artama, C.R. Tabbu, "The effect of virgin coconut oil on lymphocyte and CD4 in chicken vaccinated against avian influenza virus," J. Indonesian Trop. Anim. Agric, vol. 37(1), 2012.

[70] M. Shilling, L. Matt, E. Rubin, M.P. Visitacion, N.A. Haller, S.F. Grey, C.J. Woolverton, "Antimicrobial effects of virgin coconut oil and its medium-chain fatty acids on Clostridium 
difficile," Journal of Medicinal Food, vol. 16(12), pp. 10791085, 2013.

[71] J.J. Kabara, D.L. Marshall, Medium-chain fatty acids and esters. In: P.M. Davison, J.N. Sofos, J.L. Brannen, eds. Antimicrobials in food. $3^{\text {rd }}$ ed. Boca Raton: CRD Press, 2005, pp. 327-60.

[72] H. Zhang, Y. Shen, Weng P, et al., "Antimicrobial activity of a food-grade fully dilutable microemulsion against Escherichia coli and Staphylococcus aureus," Int. J. Food Microbiol., vol. 135, pp. 211-215, 2009.

[73] A.D. Warth, "Transport of benzoic and propanoic acids by Zygosaccharomyces bailii," J. Gen. Microbiol., vol. 135, pp. 1383-1390, 1989.
[74] C.A. Voegas, I. Sa-Correia. "Activation of plasma membrane ATPase of Saccharomyces cerevisiae by octanoic acid," J. Gen. Microbiol., vol. 137, pp. 645-651, 1991.

[75] G. Ismail, W.D. Sawyer, W.S. Wegener. "Effect of hydrogen peroxide and superoxide radical on viability of Neisseria gonnorrhoeae and related bacteria," Proc. Soc. Exp. Biol. Med., vol. 155, pp. 264-269, 1977.

[76] H.R. Knapp, M.A. Melly, "Bactericidal effect of polyunsaturated fatty acids," J. Infect. Dis., vol. 154, pp. 84-94, 1986. 